\title{
Evaluation of polycyclic aromatic hydrocarbons in Achyrocline Satureioides (Marcela) and its infusion
}

This study evaluates the presence and levels of polycyclic aromatic hydrocarbons (PAHs) in Achyrocline Satureioides (inflorescences and infusions) using extraction under ultrasound accompanied by clean up with solid phase extraction (SPE) and gas chromatography coupled to mass spectrometry. Sixteen priority PAHs were listed as priority contaminants by the United States Environmental Protection Agency and PAHs (Benzo(a)Anthracene, Chrysene, Benzo(b)Fluoranthene, Benzo(a)Pyrene) were chosen as indicators by the European Food Safety Agency for the presence of PAHs in food. The HPAs concentrations ranged from $48.1 \mu \mathrm{g}$ $\mathrm{Kg}-1 \pm 1.4 \%$ to $48.8 \mu \mathrm{g} \mathrm{Kg}-1 \pm 1.9 \%$ in Achyrocline Satureioides inflorescences. The total concentration in infusions of PAHs was $2.5 \mu \mathrm{L}$ - $1 \pm 6.3 \%$. The sum of the priority PAHs in Achyrocline Satureioides samples ranged from $126.8 \mu \mathrm{g} \mathrm{Kg}-1 \pm 13.6 \%$ and $218.9 \mu \mathrm{g} \mathrm{Kg}-1 \pm 16.1 \%$ and infusion had a value of $10.0 \mu \mathrm{g} \mathrm{L}-1 \pm 8.1 \%$. The PAH concentrations in tea infusions are lower when compared with other food matrices, but the migration of these compounds for tea is high, resulting in levels that may cause damage to health.

Keywords: PAHs; Marcela; Infusions; SPE; GC/MS.

\section{Avaliação de hidrocarbonetos policíclicos aromáticos em Achyrocline Satureioides (Marcela) e sua infusão}

\begin{abstract}
Este estudo avalia a presença e os níveis de hidrocarbonetos policíclicos aromáticos (HPAs) em Achyrocline Satureioides (inflorescências e infusões) usando extração sob ultrassom acompanhada de etapas de clean up com extração em fase sólida (SPE) e determinação por cromatografia gasosa acoplada a espectrometria de massa. Dezesseis HPAs prioritários foram listados como contaminantes prioritários pela Agência de Proteção Ambiental dos Estados Unidos e HPAs (Benzo (a) Antraceno, Crisene, Benzo (b) Fluoranteno, Benzo (a) Pireno) foram escolhidos como indicadores pela Agência Europeia de Segurança Alimentar para a presença de HPAs em alimentos. As concentrações de HPAs variaram de $48,1 \mu \mathrm{g} \mathrm{Kg}-1 \pm 1,4 \%$ a $48,8 \mu \mathrm{g} \mathrm{Kg}-1 \pm 1,9 \%$ nas inflorescências de Achyrocline Satureioides. A concentração total de HPAS nas infusões foi de $2,5 \mu \mathrm{g} \mathrm{L}-1 \pm 6,3 \%$. A soma dos HPAs prioritários nas amostras de Achyrocline Satureioides variou de $126,8 \mu \mathrm{g}$ Kg-1 $\pm 13,6 \%$ e $218,9 \mu \mathrm{g} \mathrm{Kg}-1 \pm 16,1 \%$ e a infusão teve um valor de $10,0 \mu \mathrm{g} \mathrm{L}-1 \pm 8,1 \%$. As concentrações de HPAs nas infusões (chá) são menores quando comparadas com outras matrizes alimentares, mas a migração desses compostos para o chá é elevada, resultando em níveis que podem causar danos à saúde.
\end{abstract}

Palavras-chave: HPAs; Marcela; Infusões; SPE; GC/MS.

Topic: Desenvolvimento, Sustentabilidade e Meio Ambiente

Reviewed anonymously in the process of blind peer
Received: 01/01/2021

Approved: 28/01/2021
Pedro José Sanches Filho (iD

Instituto Federal Sul-Rio-Grandense, Brasil

http://lattes.cnpq.br/9785390634457316

http://orcid.org/0000-0002-9852-8940

pjsans@ibest.com.br

\section{Julia Arduim}

Instituto Federal Sul-Rio-Grandense, Brasil http://lattes.cnpq.br/4547721924522273

juliaarduim@hotmail.com

Glauco Rasmussen Betemps

Instituto Federal Sul-Rio-Grandense, Brasil http://lattes.cnpq.br/7450476222967610 glauco.betemps@gmail.com

\author{
Gabriela Oliveira Andrade (iD \\ Instituto Federal Sul-Rio-Grandense, Brasi \\ http://lattes.cnpq.br/9941272788914935 \\ http://orcid.org/0000-0001-9655-3010 \\ gab0 andrade@hotmail.com \\ Ricardo Correa da Silva da Silva \\ Instituto Federal Sul-Rio-Grandense, Brasi \\ http://lattes.cnpq.br/9612322602557280 \\ rcssmg@yahoo.com.br
}

\section{Referencing this:}

SANCHES FILHO, P. J.; ARDUIM, J.; BETEMPS, G. R.; ANDRADE, G. O.; ANDRADE, G. O.; SILVA, R. C. S.. Evaluation of polycyclic aromatic hydrocarbons in Achyrocline Satureioides (Marcela) and its infusion. Revista Ibero Americana de Ciências Ambientais, v.12, n.1, p.531543, 2021. DOI: http://doi.org/10.6008/CBPC2179-

6858.2021.001.0043 


\section{INTRODUCTION}

The Brazil and Latin America have one of the largest reservoirs of plants for herbal teas. These plants can be used for various functions, such as the production of dyes, foods, spices and medicinal use. The leaves and inflorescences of these plants are generally not consumed, but they are used in the form of infusions, as tea being one of the most consumed beverages in the world. Among them is the Achyrocline Satureioides (AS), of the family Asteraceae, also known as Marcela, Marcela-do-campo (PEREIRA et al., 2006). In addition to this, Mairesse (2005) cites Macela and National Chamomile. It can contain branches up to height of $1.5 \mathrm{~m}$, measuring $12 \mathrm{~cm}$ long by $1.8 \mathrm{~cm}$ wide with golden yellow inflorescences, as represented in Figure 1 .

It is originally from Argentina, Uruguay, Brazil and other countries of Latin America. In the South of Brazil, it can be easily found because of its spontaneous growth in pastures, roadsides and vacant lots and its harvesting period is between March and April (PEREIRA et al., 2006).

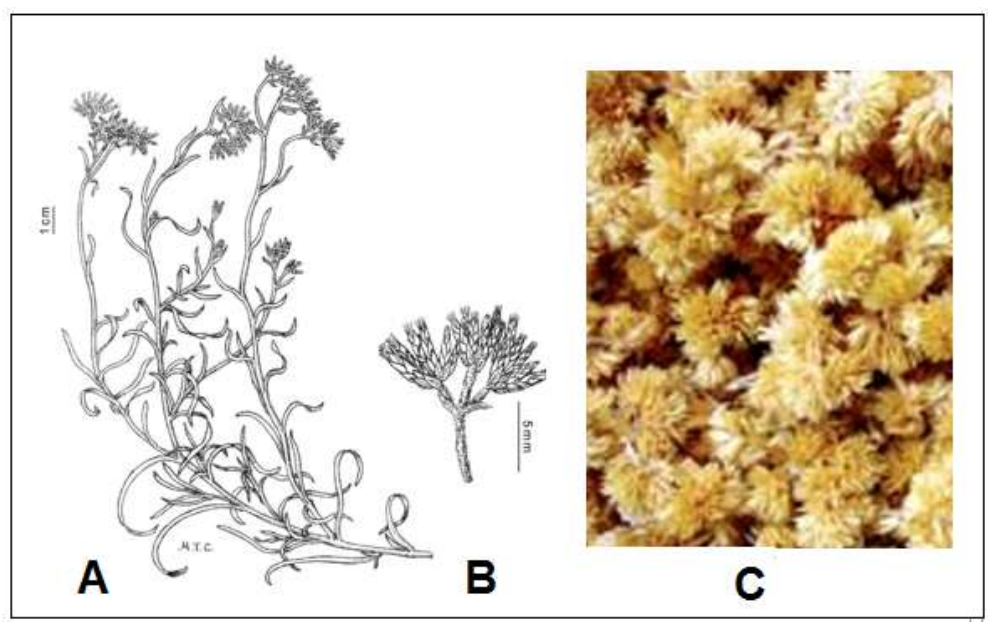

Figure 1: Illustration (A) Achyrocline Satureioides (B) inflorescences to Achyrocline Satureioides (C) photo of the inflorescences of Achyrocline Satureioides. Source: IBODA (2014).

The inflorescences of AS placed in cushions and pillows can be used as a soothing, aromatic substance and painkiller. Their infusions made in boiling water or milk are used extremely in south of Brazil to treat gastrointestinal diseases, reduce the cholesterol level in the blood, act as a digestive and anti-inflammatory, antimicrobial, antioxidant, antispasmodic and as an antipyretic drug (DESMARCHELIER et al., 1998; FACHINETTO et al., 2007; RITTER et al., 2002).

Various collection sites of this plant may reveal the presence of polycyclic aromatic hydrocarbons (PAHs). The leaves and inflorescences of AS have a high surface area, and thus can absorb and accumulate the PAHs that are present in the air (LIN et al., 2004). Being a form of diffuse contamination associated with the particulate matter, it is capable of traversing long distances by focusing on the surface of various food matrices (SINGH et al., 2011). Moreover, its presence in tea plants may be related with the drying process (BERTINETTI et al., 2018; CIEMNIAK et al., 2019; ZIEGENHALS et al., 2018).

The polycyclic aromatic hydrocarbons are a family with more than 100 organic compounds with one or more benzene rings condensed and can be divided into two classes: low molecular weight compounds (Naphthalene, Acenaphthylene, Acenaphthene, Anthracene, Phenanthrene, and Fluorene) and high 
molecular mass compounds (Fluoranthene, Pyrene, Benzo(a)Anthracene, Chrysene, Benzo(b)Fluoranthene, Benzo(k)Fluoranthene, Benzo(a)Pyrene, Dibenzo(a, h)Anthracene, Benzo(g, h, i)Perylene, Indene(1, 2, 3cd)Pyrene) (LONDOÑO et al., 2014). These 16 PAHs presented in Figure 2 are listed by the European Union (EU) and the United States Environmental Protection Agency (USEPA) as priority contaminants. These compounds are formed from the incomplete combustion of organic matter such as wood, coal and petroleum derivatives (BERTINETTI et al., 2018; ZIEGENHALS et al., 2018). They have a low water solubility and high Kow (octanol/water partition coefficient) (AZEVEDO et al., 2013).

Being a class with hundreds of compounds and to make a control of these, the Contaminants in the Food Chain (CONTAM) along with the European Food Safety Authority (EFSA) attributed Chrysene, Benzo(a)Anthracene, Benzo(b)Fluoranthene and Benzo(a)Pyrene as indicators of PAHs in foods, and are defined as PAHs (EFSA, 2008).

As the environmental contamination by PAHs has aroused global concern, many studies have examined these contaminants in different food matrices. Paris et al. (2018) assessed the level of PAHs in fruits, Tfouni et al. (2014) in vegetable oil blends, and Serpe et al. (2010) in mussels. Studies also have been developed in coffee (FALCON et al., 2005), Cocoa beans (CIECIERSKA, 2020) and in different teas, like black tea, Indian tea, jasmine tea, among others (DABORAVA et al., 2012; ISHIZAKI et al., 2010; LONDOÑO et al., 2015; TRAN-LAN et al., 2018) as well as of their infusions (GIRELLI et al., 2017; LIN et al., 2005; PINCEMAILLE et al., 2014). These studies suggest that food intake is one of the main routes of human exposure to these contaminants.

The PAH study on medicinal plants is justified by its carcinogenic, mutagenic and immune suppressive properties. They are becoming not only an environmental issue but also as a public health problem (RENGARAJAN et al., 2015).

There are just a few studies and analyzes on the contamination of PAHs. Considering the degree of toxicity of these compounds and the larger presence in our daily life, the objective of this study is optimizing a methodology, combining ultrasound extraction and solid phase extraction steps, to determine determine the levels of PAHs in inflorescences of $A$. Satureioides and in its infusions.

\section{MATERIALS AND METHODS}

\section{Samples}

The samples used in this study were classified into two groups as presented in table 1.

Table 1: Groups of samples used for evaluation of PAH in AS and infusion.

\begin{tabular}{|c|c|}
\hline GROUP 1: Samples collected by the authors & GROUP 2: Commercially available samples \\
\hline $\begin{array}{l}5 \text { specimens of AS1 sample was collected at the federal highway } \\
\text { BR } 392 \text { (coordinates: } 31^{\circ} 40^{\prime} 57.70^{\prime} \mathrm{S} ; 52^{\circ} 26^{\prime} 42.32^{\prime \prime} \mathrm{W} \text { ). } \\
5 \text { specimens of AS2 sample was collected in the rural area of } \\
\text { Pelotas city/Brazil (coordinates: } 31^{\circ} 40^{\prime} 58.22^{\prime} \mathrm{S} ; 52^{\circ} 27^{\prime} 10.64^{\prime \prime} \mathrm{W} \text { ), } \\
\text { about } 500 \mathrm{~m} \text { from the federal highway BR } 392 \text {. }\end{array}$ & $\begin{array}{l}5 \text { sample presentations AS3 obtained from the informal trade } \\
\text { of herbs (tea sellers). } \\
\text { The AS4 sample purchased from local commercial } \\
\text { establishments, in commercial packaging, consisting mainly of } \\
\text { inflorescences packed in sachets ready for infusion. }\end{array}$ \\
\hline $\begin{array}{l}\text { The specimens were collected for each point resulting in a } \\
\text { composite sample. }\end{array}$ & $\begin{array}{l}\text { AS3 sample presentations were met, resulting in a composite } \\
\text { sample. }\end{array}$ \\
\hline
\end{tabular}


All samples were acquired in April 2016, after collection they were separated as inflorescences of other components of AS (stems, leaves) and were placed in previously decontaminated glass jars and only this part of the plant was used for the analysis. Analyses were performed in triplicate, for the determination of moisture and levels of sixteen priority PAHs according to the USEPA. The AS1 samples were used to assess the transfer of these analytes for infusion.

\section{Solvents and reagents}

To determine the PAH content, two standard mix (M1 and M2) were used. The M1 consists of 16 PAHs (Naphthalene, Acenaphthylene, Acenaphthene, Fluorene, Phenanthrene, anthracene, fluoranthene, Pyrene, Benzo(a)anthracene, chrysene, Benzo(b)fluoranthene, Benzo(k)fluoranthene, Benzo(a)pyrene, indeno( 1,2,3-c, d)pyrene, dibenzo(a, h)anthracene, benzo(g, h, i)Perylene) $2000 \mathrm{mg} \mathrm{L}^{-1}$ purchased from Supelco (Bellefonte, PA, USA). The M2 consists of standard deuterateds PAHs (Phenanthrene-D10, chryseneD12 and perylene - D12), $2000 \mathrm{mg} \mathrm{L}^{-1}$, purchased from Supelco (Bellefonte, PA, USA). Standard C8-C20 and C21-C40, $40 \mathrm{mg} \mathrm{L}^{-1}$ purchased from Sigma-Aldrich were used to study $\mathrm{n}$-alkanes. The solvents and reagents used for extraction and clean-up by preparative liquid chromatography column were: hexane, dichloromethane, methanol, acetone, anhydrous sodium sulfate and silica gel (70-230 mesh ASTM) purchased from Merck Chemical Industries. The ultrapure water was obtained through a Milli-Q water purification system (Millipore Co.).

\section{Determination of moisture}

The determination of the moisture of the samples was performed by the indirect method. $2.0 \mathrm{~g}$ of inflorescences from each sample were placed in an oven at $100-105^{\circ} \mathrm{C}$ until constant weight. Moisture was calculated by weight difference, and expressed as a percentage (BORGES et al., 2005).

\section{Extraction of (PAHs) in AchyroclineSatureioides}

The PAHs extraction of the samples was based on three extraction techniques reported for other vegetable matrices (BETTIN et al., 2005; LIN et al., 2005; PINCEMAILLE et al., 2014). The samples ( $\pm 2.0 \mathrm{~g}$ ) were added to $15.0 \mathrm{~mL}$ of hexane/acetone solution $(94: 6, \mathrm{v} / \mathrm{v}$ ) and sonicated (40 kHz frequency) in a thermostated bath at $30^{\circ} \mathrm{C}$ (USC 4800A Unique) for 15 minutes. Extract being separated by simple filtration and the solvent being evaporated in an ice bath under gentle nitrogen flow.

To evaluate the performance of extraction, a mass of $2.0 \mathrm{~g}$ AS (AS1) was fortified with $20 \mu \mathrm{g} \mathrm{Kg}^{-1}$ of the M2 mixture (Phenanthrene - D10, chrysene - D12 and perylene-D12).

\section{Polycyclic aromatic hydrocarbons extraction (PAHs) in infusion of Achyrocline Satureioides}

For the preparation of infusion, $2.0 \mathrm{~g}$ of the sample was added to the $100 \mathrm{~mL}$ of ultrapure water at temperature of $80^{\circ} \mathrm{C}$ for 10 minutes. After preparation, the extract was vacuum filtered, so that there was no interference from the suspended material from the inflorescences in solid phase extraction (SPE). This 
procedure was adapted from Pincemaille et al. (2014).

\section{Preparative column chromatography (PLC) on silica gel}

The extracts were fractionated in a glass column $(21 \times 1.1 \mathrm{~cm}$ i.d.) filled with $3.0 \mathrm{~g}$ silica gel 60 (70230 mesh ASTM), deactivated with 15\% water, and $2.0 \mathrm{~g}$ anhydrous sodium sulfate. Extract was applied in the column and was eluted by gravity with $5.0 \mathrm{~mL}$ of hexane to fraction $\mathrm{F} 1$ (aliphatic) and $25.0 \mathrm{~mL}$ of dichloromethane/hexane $(1: 4, v / v)$ to the fraction F2 (PAHs).

\section{Extraction in solid phase SPE C18}

The volume of infusion was fixed at $50.0 \mathrm{~mL}$ for each sample. Then the infusion was pre-concentrated by SPE in a C18 cartridges (Chromabond ${ }^{\circledR}$ C18 EC $6 \mathrm{~mL} / 1000 \mathrm{mg}$ ), previously activated with $2.0 \mathrm{~mL}$ of methanol and $1.0 \mathrm{~mL}$ of distilled water. The analytes were eluted with $5.0 \mathrm{~mL}$ of acetone and $5.0 \mathrm{~mL}$ of DCM. After evaporation, this extract was fractionated using a silica gel column, the same components, reagents and solvents used for fractionation of AS samples.

To evaluate the performance of extraction, $50.0 \mathrm{~mL}$ of aqueous extracts (AS1) were spiked with 2.0 $\mu \mathrm{g} \mathrm{L}^{-1}$ of each deuterated standard (mixture $\mathrm{M} 2$ ).

\section{Chromatographic analysis GC/MS}

The volume of the fractions $\mathrm{F} 1$ and $\mathrm{F} 2$ was adjusted to $1 \mathrm{~mL}$ with dichloromethane, under a gentle stream of nitrogen for analysis by gas chromatography coupled to mass spectrometer.

An aliquot of $1 \mu \mathrm{L}$ of each extract (in triplicate) was automatically injected in splitless mode in gas chromatograph coupled to the mass spectrometer (GC/MS-QP2010 Ultra Shimadzu), being equipped with auto-sampler AOC-20i Shimadzu. The chromatographic conditions are shown in Table 2. Quantification of PAHs was acquired in a SIM mode (single ion monitoring). The identification of the compounds was based on the retention time of each analyte in comparison with those of the standard mixture (M1) and $\mathrm{m} / \mathrm{z}$ corresponding to each compound.

In order to verify the performance of the chromatographic method and quantify PAHs, the calibration curve was constructed within a range of $20-200 \mu \mathrm{g} \mathrm{L} \mathrm{L}^{-1}$, using standard solutions containing 16 PAHs (EPA priority Pollutants). The accuracy of the chromatographic method was developed by repeating 11 times the standard analysis of $50 \mu \mathrm{g} \mathrm{L}^{-1}$.

All the procedures were followed with blank analysis to evaluate potential interference of environmental contaminants as well as laboratory reagents.

The limit of detection (LOD) was calculated using the sum of the average blank signal over three times its standard deviation. The limit of quantification (LOQ) was calculated as the sum of the white signal with ten times the standard deviation. For the calculation of the LOD and LOQ method, a mass of $2.0 \mathrm{~g}$ of inflorescences and $50.0 \mathrm{~mL}$ was considered for the infusions with a recovery of $100 \%$ for each analyte. Recoveries were calculated by ratio between the amount of deuterated PAHs found and the amount of 
deuterated PAHs added, multiplying by 100.

Table 2: Chromatographic conditions for GC/MS analysis.

\begin{tabular}{|c|c|}
\hline Parameter & Specification \\
\hline Column & $\begin{array}{l}\text { RTX-5ms column ( } 30 \mathrm{~m} \times 0.25 \mathrm{~mm} \text { id } \times 0.25 \mu \mathrm{m} \text { film thickness) (J \& W Scientific, Folsom, CA, } \\
\text { USA) }\end{array}$ \\
\hline Injection mode & Splitless \\
\hline Injector temperature & $280^{\circ} \mathrm{C}$ \\
\hline Interface Temperature & $200^{\circ} \mathrm{C}$ \\
\hline ionization & Electron impact (EI) at $70 \mathrm{eV}$ \\
\hline Carrier gas / flow & Helium $\left(1.0 \mathrm{~mL} \mathrm{~min}^{-1)}\right.$ \\
\hline Oven temperature (F2) & Initial temperature $80^{\circ} \mathrm{C}(5 \mathrm{~min}) 8^{\circ} \mathrm{C} \min ^{-1}, 160^{\circ} \mathrm{C}(0 \mathrm{~min}) 3^{\circ} \mathrm{C} 280^{\circ} \mathrm{C}^{-1} \mathrm{~min}(15 \mathrm{~min})$. \\
\hline $\begin{array}{l}\text { Oven temperature (F1 SCAN } \\
\text { mode) }\end{array}$ & Initial temperature $60^{\circ} \mathrm{C}(5 \mathrm{~min}) 8^{\circ} \mathrm{C} \mathrm{m^{-1 }}, 160^{\circ} \mathrm{C}(0 \mathrm{~min}) 3^{\circ} \mathrm{C} 280^{\circ} \mathrm{C}^{-1} \mathrm{~min}(15 \mathrm{~min})$ \\
\hline lons Monitored (SIM mode) & $\mathrm{m} / \mathrm{z}: 128,152,154,166,178,202,228,252,276,278$ \\
\hline \multicolumn{2}{|l|}{$\mathrm{PAHs}$} \\
\hline Ions Monitored (SIM mode) & $\mathrm{m} / \mathrm{z}: 188,240,264$ \\
\hline Deuterated PAHs & \\
\hline
\end{tabular}

\section{RESULTS AND DISCUSSION}

\section{Validation}

Table 3 shows the Calibration parameters for the proposed method of PAH analysis in AS and and its infusion. It can be observed that the working range we studied (20 a $\left.200 \mathrm{\mu g} \mathrm{L}^{-1}\right)$ presented a linear response equipment through the correlation coefficient ranging from $0.980-0.999$. The accuracy of the chromatographic method expressed through relative standard deviation (0.4 to $0.9 \%$ ) were considered equivalent to that found by other authors in PAH analysis for plant samples as Pincemaille et al. (2014) and suitable for chromatographic methods according to the literature (MEDEIROS et al., 2007).

Tabela 3: Calibration parameters of quantitative method.

\begin{tabular}{|c|c|c|c|c|c|c|}
\hline & $Y=a X+k$ & & & $\begin{array}{l}\text { AS } \\
\mu \mathrm{g} \mathrm{Kg}^{-1}\end{array}$ & & $\begin{array}{l}\text { AS Infusion } \\
\mu \mathrm{g} \mathrm{L}^{-1}\end{array}$ \\
\hline PAHs & $\mathrm{a}$ & $\mathrm{b}$ & $r^{2}$ & LOD/LOQ & $\%$ RSD & LOD/LOQ \\
\hline Naphthalene & 715.6 & -17206.5 & 0.993 & $0.4 / 0.9$ & 0.5 & $0.03 / 0.08$ \\
\hline Acenaphthylene & 429.8 & -9966.5 & 0.999 & $0.2 / 0.4$ & 0.5 & $0.01 / 0.03$ \\
\hline Acenaphthene & 271.3 & -5692.5 & 0.998 & $0.6 / 1.6$ & 0.4 & $0.05 / 0.13$ \\
\hline Fluorene & 270.1 & -8224.0 & 0.996 & $0.5 / 1.2$ & 0.4 & $0.04 / 0.10$ \\
\hline Phenanthrene & 333.0 & -14116.0 & 0.989 & $0.8 / 2.3$ & 0.4 & $0.07 / 0.18$ \\
\hline Anthracene & 389.1 & -19700.0 & 0.987 & $0.6 / 1.5$ & 0.4 & $0.16 / 0.44$ \\
\hline Fluoranthene & 364.9 & -11160.0 & 0.997 & $0.3 / 1.0$ & 0.4 & $0.03 / 0.08$ \\
\hline Pyrene & 392.1 & -11668.5 & 0.998 & $0.3 / 0.9$ & 0.4 & $0.03 / 0.08$ \\
\hline Benzo (a) anthracene & 154.0 & -5873.5 & 0.999 & $0.8 / 2.3$ & 0.5 & $0.17 / 0.43$ \\
\hline Chrysene & 245.4 & -11339.0 & 0.991 & $0.9 / 2.5$ & 0.5 & $0.20 / 0.52$ \\
\hline Benzo (k) fluoranthene & 137.0 & -5324.0 & 0.999 & $0.9 / 2.4$ & 0.6 & $0.17 / 0.44$ \\
\hline Benzo (b) fluoranthene & 205.1 & -8717.5 & 0.999 & $0.8 / 2.1$ & 0.5 & $0.16 / 0.40$ \\
\hline Benzo (a) pyrene & 116.1 & -2631.5 & 0.993 & $1.1 / 2.9$ & 0.6 & $0.15 / 0.39$ \\
\hline Benzo $(g, h, i)$ Perylene & 55.7 & -1674.0 & 0.989 & $1.1 / 2.9$ & 0.8 & $0.24 / 0.63$ \\
\hline Dibenzo $(a, h)$ anthracene & 40.7 & -923.0 & 0.980 & $1.3 / 3.3$ & 0.7 & $0.10 / 0.27$ \\
\hline Indeno $(1,2,3-c, d)$ pyrene & 96.0 & -2657.5 & 0,999 & $1.2 / 3.2$ & 0.9 & $0.23 / 0.60$ \\
\hline
\end{tabular}

$\mathrm{Y}=\mathrm{aX}+\mathrm{b}$ (a-angular coefficient; $b$-linear coefficient); $\mathrm{r}^{2}$ : linear correlation coefficient; LOD: Limit of detection; LOQ: Limit of quantification; \%RSD: relative standard deviations in \%.

The LOD and LOQ for AS ranged from $0.2-1.3 \mu \mathrm{g} \mathrm{Kg}^{-1}$ and $0.4-3.3 \mu \mathrm{g} \mathrm{Kg}^{-1}$, respectively. It is observed that the highest values relate to compounds that have lower response factor. The values are similar to those described by Londoño et al. (2015) in his work with tea (Camellia sinensis). The LOD and LOQ for infusion 
were found in the range 0.01 to $0.24 \mu \mathrm{g} \mathrm{L}^{-1}$ and 0.03 to $0.63 \mu \mathrm{g} \mathrm{L}^{-1}$, values equivalents to the determined by Lin et al. (2005) for different types of infusion. It is observed that the LOD and LOQ for the SPE process are lower when using a larger sample volume.

Table 4 presents the results of studies of recovery for both solid samples as to the method of extraction by SPE for the infusion.

Table 4: The recovery study for AS samples $\left(\mu \mathrm{Kg}^{-1}\right)$ and AS infusion $\left(\mu \mathrm{g} \mathrm{L}^{-1}\right) \pm$ relative standard deviations $( \pm \mathrm{RSD} \%)$.

\begin{tabular}{lllllll}
\hline & AS $\mu \mathrm{Kg}^{-1}$ & \multicolumn{5}{c}{ Infusion $\mu \mathrm{g} \mathrm{L}^{-1}$} \\
\hline & Value & & & Value & \\
PAHs & Fortified & Value Found & Recovery (\%) & Fortified & Value Found & Recovery (\%) \\
\hline Phenanthrene D10 & 20.0 & $15.9 \pm 8.5$ & 79.4 & 2.0 & $1.6 \pm 13.4$ & 82.5 \\
Chrysene D12 & 20.0 & $18.4 \pm 7.8$ & 92.0 & 2.0 & $2.1 \pm 9.2$ & 105.0 \\
Perylene D12 & 20.0 & $18.7 \pm 9.0$ & 93.5 & 2.0 & $1.8 \pm 8.7$ & 91.0 \\
\hline
\end{tabular}

The amounts described in Table 4 are equivalent to those published by other authors who have worked with this type of matrix. Daborava et al. (2012) found values for recoveries in the range of $80-103 \%$ and Ziegenhals et al. (2018) of $75-117 \%$.

Moreover, these values also meet the requirements for this type of determination, as the recovery of $50-120 \%$ by the EU regulation $835 / 2011$ and the opinion of EFSA along with the CONTAM.

\section{Results in Achyrocline Satureioides}

On preliminary characterization, the humidity of the four samples was determined. We found the following results for the sample AS1 $9.7 \pm 2.0 \%$, AS2 of $13.0 \pm 2.4 \%$, AS3 of $11.0 \pm 1.5 \%$ and AS4 of $11.5 \pm$ 1.7\%. These values are considered adequate for this plant according to Brandão (2007).

Table 5 present the level of PAHs determined in this study to AS samples and in the infusion. The PAHs were found in all samples tested, predominantly in the compounds of lower molecular weight ( 2 to 4 rings). The total $\Sigma \mathrm{PAH}$ in samples AS ranged were from $126.8 \mu \mathrm{g} \mathrm{Kg}^{-1} \pm 13.6 \%$ to $218.9 \mu \mathrm{g} \mathrm{Kg}^{-1} \pm 16.1 \%$. These concentrations are below to those found by Lin et al. (2005) and Londoño et al. (2015), which showed IPAHs between $323 \mu \mathrm{g} \mathrm{Kg}^{-1}$ to $8800 \mu \mathrm{g} \mathrm{Kg}{ }^{-1}$ and $509.7 \mu \mathrm{g} \mathrm{Kg}^{-1}$ to $2746.5 \mu \mathrm{g} \mathrm{kg}^{-1}$, respectively, indicating that the levels of PAHs found in this work are not high. The major compound in all samples was the Phenanthrene, followed by Chrysene. PAHs of 3 to 4 rings may be related to resulting from vehicular combustion of gasoline and diesel (AZEVEDO et al., 2013).

This situation suggests this source as the main reason for the contamination of AS. It is observed that both sample of AS1 and AS2 have very close values of these two PAHs $44.2 \mu \mathrm{gg}^{-1} \pm 13.3 \%$ and $53.3 \mu \mathrm{gg}^{-1}$ $\pm 14.2 \%$ for Phenanthrene and $27.1 \mu \mathrm{g} \mathrm{Kg}^{-1} \pm 1.0 \%$ and $26.4 \mu \mathrm{g} \mathrm{Kg}^{-1} \pm 2.9 \%$ for the chrysene respectively. Both samples show a very similar chromatographic profile suggesting the same source of PAHs and demonstrating its spread from the highway, since the AS2 sample was taken $500 \mathrm{~m}$ from federal highway BR 392.

The Naphthalene, Acenaphthene, phenanthrene, anthracene, fluoranthene, pyrene were detected and quantified in all AS samples. The chrysene and Benzo(a)anthracene were not detected only in AS3 sample. 
Table 5: PAH concentrations in $\mu \mathrm{g} \mathrm{Kg}^{-1} / \mu \mathrm{g} \mathrm{L}^{-1} \pm \mathrm{RSD} \%$ (relative standard deviation expressed in \%) on a dry basis and an infusion, determined in AS samples.

\begin{tabular}{|c|c|c|c|c|c|c|c|}
\hline \multirow[t]{2}{*}{ PAHs } & \multicolumn{4}{|l|}{$\mathrm{AS}\left(\mu \mathrm{g} \mathrm{Kg}{ }^{-1}\right)$} & \multirow{2}{*}{$\begin{array}{l}\text { Infusion } \\
\mu \mathrm{g} \mathrm{L}^{-1} \\
\text { IAS1 }\end{array}$} & \multicolumn{2}{|c|}{ Established limit } \\
\hline & AS1 & AS2 & AS3 & AS4 & & $\begin{array}{l}\text { AS } \\
\mu \mathrm{K} \mathrm{Kg}^{-1}\end{array}$ & $\begin{array}{l}\text { INF } \\
\mu g L^{-1}\end{array}$ \\
\hline Naphthalene & $14.1 \pm 3.4$ & $14.0 \pm 0.3$ & $13.7 \pm 4.2$ & $14.0 \pm 0.4$ & $0.4 \pm 27.5$ & & \\
\hline Acenaphthylene & $\mathrm{Nd}$ & $\mathrm{Nd}$ & $\mathrm{Nd}$ & $\mathrm{Nd}$ & $\mathrm{Nd}$ & & \\
\hline Acenaphthene & $13.9 \pm 13.5$ & $12.1 \pm 1.0$ & $13.2 \pm 3.8$ & $15.8 \pm 16.5$ & $0.9 \pm 7.7$ & & \\
\hline Fluorene & $18.7 \pm 12.2$ & $23.8 \pm 0.1$ & $18.2 \pm 3.3$ & $24.0 \pm 0.5$ & $1.2 \pm 24.2$ & & \\
\hline Phenanthrene & $44.2 \pm 13.3$ & $53.3 \pm 14.2$ & $34.1 \pm 1.4$ & $70.7 \pm 19.3$ & $1.7 \pm 12.3$ & & \\
\hline Anthracene & $2.9 \pm 3.0$ & $5.2 \pm 18.9$ & $2.83 \pm 5.1$ & $3.11 \pm 8.3$ & $0.2 \pm 27.1$ & & \\
\hline Fluoranthene & $19.0 \pm 5.1$ & $19.7 \pm 0.1$ & $17.6 \pm 4.9$ & $20.7 \pm 14.4$ & $0.5 \pm 11.2$ & & \\
\hline Pyrene & $20.0 \pm 11.7$ & $20.6 \pm 1.2$ & $17.5 \pm 5.3$ & $22.3 \pm 24.9$ & $0.5 \pm 13.2$ & & \\
\hline Benzo (a) anthracene & $21.7 \pm 0.4$ & $21.5 \pm 2.0$ & $\mathrm{Nd}$ & $21.7 \pm 0.9$ & $0.7 \pm 6.4$ & & \\
\hline Chrysene & $27.1 \pm 1.0$ & $26.4 \pm 2.9$ & $\mathrm{Nd}$ & $26.7 \pm 3.9$ & $0.9 \pm 9.2$ & & \\
\hline Benzo (k) fluoranthene & $\mathrm{Nd}$ & $\mathrm{Nd}$ & $\mathrm{Nd}$ & $\mathrm{Nd}$ & $0.8 \pm 6.6$ & & \\
\hline Benzo (b) fluoranthene & IT & IT & IT & IT & $0.7 \pm 3.5$ & & \\
\hline Benzo (a) pyrene & IT & IT & IT & IT & IT & & \\
\hline Benzo $(g, h, i)$ perylene & $\mathrm{Nd}$ & $\mathrm{Nd}$ & $\mathrm{Nd}$ & $\mathrm{Nd}$ & $0.7 \pm 18.6$ & & \\
\hline Dibenzo $(a, h)$ anthracene & $\mathrm{Nd}$ & $\mathrm{Nd}$ & $\mathrm{Nd}$ & $\mathrm{Nd}$ & $0.4 \pm 35.5$ & & \\
\hline Indeno $(1,2,3-c, d)$ pyrene & IT & IT & IT & IT & IT & & \\
\hline Total & $182.2 \pm 3.3$ & $196.86 \pm 5.0$ & $126.8 \pm 13.6$ & $218.9 \pm 16.1$ & $10.0 \pm 8.1$ & & $25.0^{*}$ \\
\hline $\mathrm{Cri}+\mathrm{B}(\mathrm{a}) \mathrm{A}+\mathrm{B}(\mathrm{b}) \mathrm{Fluo}+\mathrm{B}(\mathrm{a}) \mathrm{P}$ & $48.8 \pm 0.6$ & $48.1 \pm 1.4$ & $\mathrm{Nc}$ & $48.4 \pm 1.9$ & $2.5 \pm 6.3$ & $35.0 * *$ & \\
\hline$B(b)$ Fluo $+B(k)$ Fluo $+B(g, h, i) P+I(1,2,3-c, d) P$ & $\mathrm{Nc}$ & $\mathrm{Nc}$ & $\mathrm{Nc}$ & $\mathrm{Nc}$ & $2.3 \pm 8.8$ & $5.0^{*}$ & $0.10 * * *$ \\
\hline
\end{tabular}

*Established limit for the total sum of PAHs by the German Society for Fat Science; **Regulation 835/2011/EC; ***Regulation 98/83/EC; Nd: not detected; Nc: not calculed; IT: under interference; AS1: AS collected the margins of BR; AS2: AS commercial presentation; AS3: AS acquired in informal trade; AS2: AS collected in the rural area; IAS1: Infusion of sample AS AS1.Cri = chrysene; B (a) A=Benzo(a)anthracene; B (b) Fluo=Benzo(b)fluoranthene; B (a) P=Benzo(a)pyrene; B (k) Fluo=Benzo(k)fluoranthene; B (g, h, i) P=Benzo(g, h, i)Perylene; I (1,2,3-c, d) P=Indeno (1,2,3c, d) pyrene.

Acenaphthylene, Benzo(g, h, i)perylene, Dibenzo(a, h)anthracene were not detected. Benzo(b)fluoranthene, Benzo(a)pyrene and indene(1,2,3-c, d) pyrene showed co-elution with n-alkanes C26, C27 and C31, which caused interference. Therefore, it prevented their detection and quantification. Figure 2 illustrates this situation and shows the need for optimization in the fractionation method used. By analyzing the F1 and F2 fraction in scan mode, we can check the presence of $n$-alkanes profile between $\mathrm{C} 23$ to $\mathrm{C} 33$ that were not fully eliminated in F1 fraction.

Sample AS3 presented the lowest levels of PAHs, probably because these specimens were collected in regions less impacted, while the AS4 samples showed higher levels, which may be related not only to the origin of the plant but also to the processing involved. The values found in this study are equivalent with those made by Ziegenhals et al. (2018) of $18.1 \mu \mathrm{g} \mathrm{Kg}^{-1}$ for Chrysene; Pincemaille et al. (2014) with values close to $45.4 \mu \mathrm{g} \mathrm{Kg}^{-1}$ for Chrysene and $11.3 \mu \mathrm{g} \mathrm{Kg}{ }^{-1}$ to $125.0 \mu \mathrm{g} \mathrm{Kg}^{-1}$ for Benzo(a)Antraceno. Concentrations for Chrysene and Benzo(a)anthracene presented in the current study is around the same levels of these two works.

In the $\Sigma$ PAHs, values presented in the Table 5 were calculated without benzo(a)pyrene and Benzo(b)fluoranthene, as the interferences were already being indicated. The sum $\left(48.1 \mu \mathrm{g} \mathrm{Kg}^{-1} \pm 1.4 \%\right.$ to $48.8 \mu \mathrm{g} \mathrm{Kg}^{-1} \pm 0.6 \%$ ) showed no differences for AS1 samples AS2 and AS4. The concentration values are in the range of other similar studies made by Daborava et al. (2012) with results from $6.4 \mu \mathrm{g} \mathrm{Kg}^{-1}$ to $700 \mu \mathrm{g} \mathrm{Kg}^{-1}$ and Ishizaki et al. (2010), where the levels varied from $21.6 \mu \mathrm{g} \mathrm{Kg}^{-1}$ to $65.8 \mu \mathrm{g} \mathrm{Kg}^{-1}$. Thus, even without the concentrations of Benzo(a)pyrene and Benzo(b)fluoranthene, the found concentrations exceed the limits 
considered safe for EPAHs defined in Regulation 835/2011/EC which presents the value of $35 \mathrm{\mu g} \mathrm{Kg}^{-1}$ (EC, 2011).
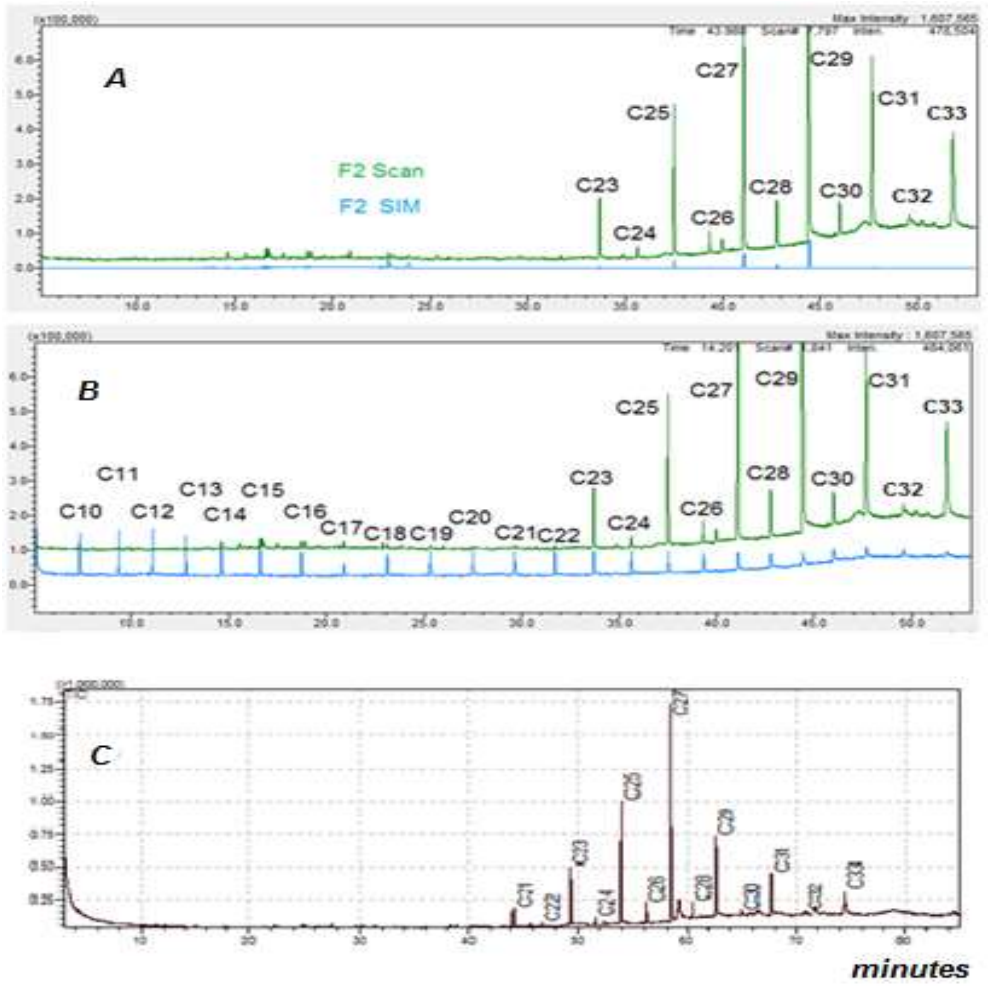

Figure 2: (A) Chromatogram of F2 fraction mode SIM and scan mode, (B) comparison of the chromatogram scan mode and the standard of n-alkanes, (C) F1 fraction (aliphatic) sample AS1.

The German Society for Fat Science also considers the amount of PAHs of higher molecular weight (Benzo(b)fluoranthene, Benzo(k)fluoranthene, Benzo(g, h, i)perylene, Indeno(1,2,3 c, d)pyrene) as a parameter and sets a limit of $5 \mu \mathrm{g} \mathrm{Kg}^{-1}$. But higher molecular weight PAHs were not detected because they were below the LD or due to interference caused by the $n$-alkanes as described above. This situation was already indicated by others authors.

\section{Results for Achyrocline Satureioides infusion}

The table 5 also shows the PAHs levels of inflorescences transferred to the infusion with the exception of Acenaphthylene compounds, which showed values below the LOD and Benzo(a)pyrene and Indene(1,2,3-c, d)pyrene, which suffered interference of n-alkanes C27 and C31. All other PAHs were detected and quantified in the samples AS infusion.

Figure 3 shows the comparison between the chromatogram of F2 fraction from the infusion and the chromatogram of the standard 16 PAHs mixture. The figure illustrates the absence of Acenaphthylene (peak 2) and interference in the Benzo(a)Pyrene (peak 13) caused by compounds C27 and in Indeno(1,2,3cd)Pyrene (peak 16) by C31.

The compounds having 3 to 4 rings in their molecular structure have been found at higher concentrations, such as phenanthrene, fluoranthene and chrysene. These results were reported by other authors such as Lin et al. (2005) $0.07 \mu \mathrm{g} \mathrm{L}^{-1}$ for Benzo(a)Antraceno and $0.06 \mu \mathrm{g} \mathrm{L}^{-1}$ for Chrysene, Pincemaille et al. (2014) found values ranging from $0.6 \mu \mathrm{g} \mathrm{L}^{-1}$ to $0.7 \mu \mathrm{g} \mathrm{L^{-1 }}$ for Benzo(a)Antraceno and $0.8 \mu \mathrm{g} \mathrm{L} \mathrm{L}^{-1}$ to $0.9 \mu \mathrm{g}$ 
$\mathrm{L}^{-1}$ for Chrysene. In infusions of herbal, values lower than those are described in this study.
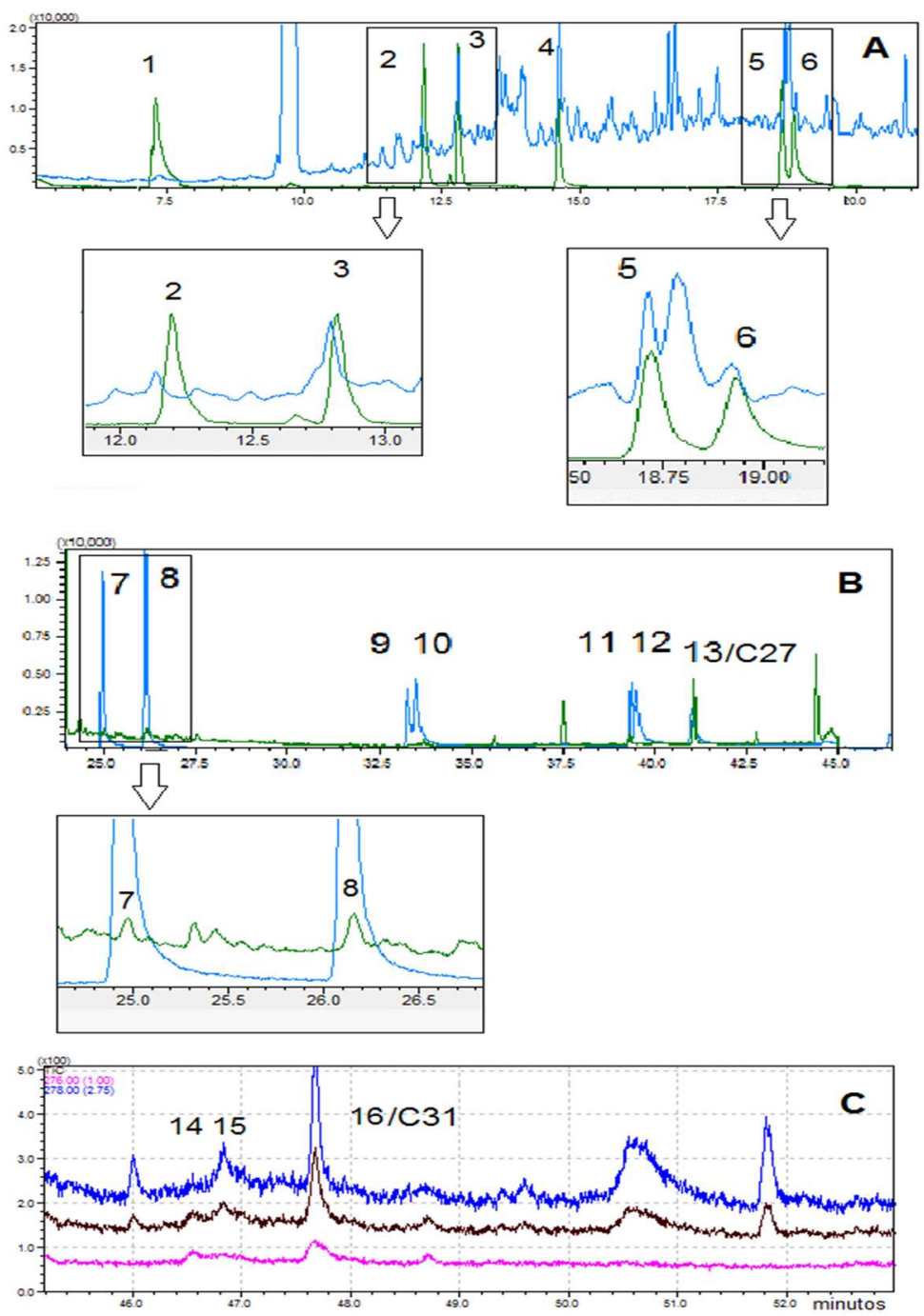

Figure 3: Chromatogram portion of the F2 fraction, which presents PAHs 1=Naphthalene, 2=Acenaphthylene, 3=Acenaphthene, 4=Fluorene, $5=$ Phenanthrene and $6=$ Anthracene (A) 7=Fluoranthene, $8=$ Pyrene, $9=$ Benzo(a)anthracene, 10=Chrysene, 11=Benzo(b)fluoranthene, 12=Benzo(k)fluoranthene, 13/C27=Benzo(a)Pyrene/n-alkane C27 (B) 14=Dibenzo(a,h)anthracene 15=Benzo(g, h, i)Perylene and 16/C31=Indene(1,2,3-cd)Pyrene/n-alkane C31 (C).

Figure 4 illustrates the efficacy of continuous phase extraction after the relationship for analyzing HPAs in the infusion. It is possible to observe the presence of homologous series of $n$-alkanes between C21 and C31 with predominance of n-alkanes with carbon chains with an odd number of carbons (C23 C27 and C29) (Fig. 4A). In Figure 4B, we verified the reduction of these peaks in F2 fraction that in the chromatogram appear in a scale 100 times smaller.

The appearance of PAHs with higher molecular weight can be explained by obtaining an extract less complex in function of the infusion. This led to a more efficient separation of the extract on PLC of silica gel, reducing interference perceived in the analysis of Achyrocline Satureioides inflorescences. Although PAHs have hydrophobic properties, the temperature of water extraction, the presence of essential oils and waxes present in inflorescences can facilitate and justify the transfer of these to the aqueous infusion (PINCEMAILLE et al., 2014). While observing the Chromatograms of the F1 fraction of both inflorescences like the infusion, we can see the presence of high levels of $n$-alkanes features of vegetable waxes. 

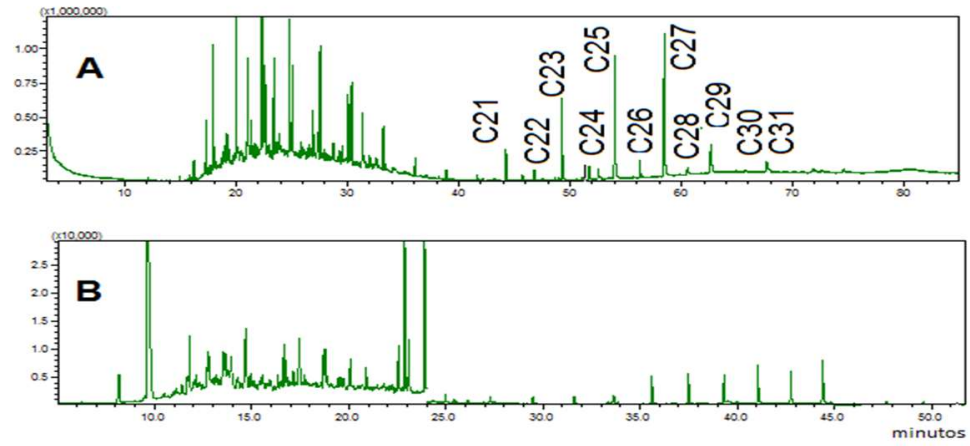

Figure 4: Chromatogram in SCAN mode (A) the fraction F1; $(B)$ fraction F2 for the sample infusion of the IAS1.

Galinaro at al. (2009) in their PAHs analysis work in alcoholic beverages used the value pre-set by the German Society for Fat Science for total PAHs of $25 \mu \mathrm{g} \mathrm{L}^{-1}$. Given that the value found in this study was 10.0 $\mu \mathrm{g} \mathrm{L}^{-1} \pm 8.1 \%$ for the total sum of PAHs in infusion, it can be considered that the tea does not present risks. The EHPAs in the infusion was lower than the limits established by regulation 835/2011/EC as the resulted value was $2.5 \mu \mathrm{g} \mathrm{L}^{-1} \pm 6.3 \%$. It was similar to the HPAs summation of Pincemaille et al. (2014), which varied from $1.4 \mu \mathrm{g} \mathrm{L}^{-1}$ to $2.7 \mu \mathrm{g} \mathrm{L}^{-1}$. But it was higher than the limit of $0.10 \mu \mathrm{g} \mathrm{L}^{-1}$ for the sum of Benzo(b)fluoranthene, Benzo(k)fluoranthene, Benzo(g, h, i)perylene and Indeno(1,2,3-c,d)pyrene in the Regulation 98/1983/EC for

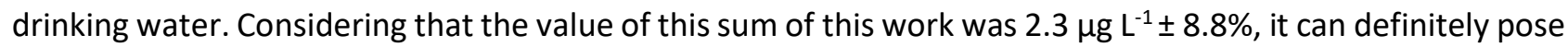
health risk.

\section{CONCLUSIONS}

The extraction method under ultrasound accompanied by pre-fractionation silica columns and analysis by GC/MS was adequate for the study of PAHs present in plant matrices as Achyrocline Satureioides. The use of SPE with C18 cartridge, followed by fractionation preparative liquid chromatography on a silica column and analysis by GC/MS allowed the determination of PAHs in the infusion levels.

The PAHs concentrations in AS sample and in the infusion were above that permitted by laws that set limits for PAHs in food. When compared to other studies, their concentrations were lower than in other vegetable matrices. However, the high concentrations in the AS infusion should be studied in more detail to assess the potential risks to health as it is present in highly consumed beverages like tea.

ACKNOWLEDGEMENTS: The authors thank to PROPESP-IFSUL for financial support.

\section{REFERENCES}

AZEVEDO, J. A. H.; ARAÚJO, R. S.; SILVA, G. M. M.. Hidrocarbonetos policíclicos aromáticos atmosféricos de fontes automotivas: uma breve revisão. Holos, v.1, p.102114, 2013. DOI: https://doi.org/10.15628/holos.2013.1234

BERTINETTI, I. A.; FERREIRA, C. D.; MONKS, J. L. F.; SANCHES FILHO, P. J.; ELIAS, M. C.. Accumulation of polycyclic aromatic hydrocarbons (PAHs) in rice subjected to drying with different fuels plus temperature, industrial processes and cooking. Journal of Food Composition and Analysis, v.66, p.109-115, 2018. DOI: https://doi.org/10.1016/j.jfca.2017.12.009

BETTIN, S. M.; FRANCO, D. W.. Hidrocarbonetos policíclicos aromáticos (HPAs) em aguardentes. Ciência e Tecnologia de Alimententos, Campinas, v.25, n.2, p.234-238, 2005. DOI: http://dx.doi.org/10.1590/S0101-20612005000200008

BORGES, D. B.; FARIAS, M. R.; SIMOES, C. M. O.; SCHENKEL, E. P.. Comparação das metodologias da Farmacopéia Brasileira para determinação de água em matérias-primas vegetais, e validação da determinação de água em 
analisador de umidade para Calendula officinalis L., Foeniculum vulgare Miller, Maytenus ilicifolia Mart. ex. Reissek e Passiflora alata Curtis. Revista Brasileira Farmacognosia, v.15, n.3, p.229-236, 2005. DOI: https://doi.org/10.1590/S0102-695X2005000300013

BRANDÃO, M. G. L.. Produção de chás e extratos de plantas medicinais. Dossiê Técnico - Serviço Brasileiro de Respostas Técnicas, 2007.

CIECIERSKA, M.. Cocoa beans of different origins and varieties and their derived products contamination with polycyclic aromatic hydrocarbons. Food Chemistry, v.317, 2020. DOI:

https://doi.org/10.1016/j.foodchem.2020.126408

CIEMNIAK, A.; KUZMICZ, K.; RAJKOWSKA-MYSLIWIEC, M.. Assessing the contamination levels of dried teas and their infusions by polycyclic aromatic hydrocarbons (PAHs). Journal of Consumer Protection and Food Safety, v.14, p.263-274, 2019. DOI: https://doi.org/10.1007/s00003-01901229-1

DABORAVA, L.; PULKRABOVA, J.; KALACHOVA, K.; TOMANIOVA, M.; KOCOUREKk, V.; HAJSLOVA J.. Rapid determination of polycyclic aromatic hydrocarbons (PAHs) in tea using two-dimensional gas chromatography coupled with time of flight mass spectrometry. Talanta, v.100, p.207216, 2012. DOI: https://doi.org/10.1016/i.talanta.2012.07.081

DESMARCHELIER, C.; COUSSIO, J.; CICCIA, G.. Antioxidant and free radical scavenging effects in extracts of the medicinal herb Achyroclinesatureioides (Lam.) DC. Brazilian Journal of Medical and Biological Research v.31, n.9, p.1163-1170, 1998. DOI: http://dx.doi.org/10.1590/\$0100$\underline{879 \times 1998000900010}$

EC. European Commission. Commission regulation (EU) n. $835 / 2011$ amending regulation (EC) no 1881/2006 as regards maximum levels for polycyclic aromatic hydrocarbons in foodstuffs. Official Journal of European Commission, v.215, p.7-8, 2011.

EFSA. European Food Safety Agency. Polycyclic aromatic hydrocarbons in food. The EFSA Journal, v.724, p.96-114, 2008. DOI: https://doi.org/10.2903/j.efsa.2008.724

FACHINETTO, J. M.; BAGATINI, M. D.; DURIGON, J.; SILVA, A. C. F.; TEDESCO, S. B.. Efeito anti-proliferativo das infusões de Achyrocline satureioides DC (Asteraceae) sobre o ciclo celular de Allium cepa. Revista Brasileira Farmacognosia, João Pessoa, v.17, n.1, p.49-54, 2007. DOI: http://dx.doi.org/10.1590/S0102-695X2007000100011

FALCON, M. S. G.; GRANDE, B. C.; GANDARA, J. S.. Minimal cleanup and rapid determination of polycyclic aromatic hydrocarbons in instant coffee. Food Chemistry, v.90, n.4, p.643-647, 2005. DOI:

https://doi.org/10.1016/j.foodchem.2004.03.059

GALINARO, C. A.; FRANCO, D. W.. Polycyclic aromatic hydrocarbons (PAHS) in cachaça, rum, whiskey and alcohol fuel. Química Nova, São Paulo, v.32, n.6, p.1447-1451, 2009. DOI: http://dx.doi.org/10.1590/S0100-40422009000600016

GIRELLI, A. M.; APRICENO, A.; TAROLA, A. M.; TORTORA, F..
Determination of Polycyclic Aromatic Hydrocarbons in Tea Infusions Samples by High Performance Liquid Chromatography with Fluorimetric Detection. Journal of Food Quality, v.2017, p.1-7, 2017. DOI: https://doi.org/10.1155/2017/1076876

ISHIZAKI, A.; SAITO, K.; HANIOKA, N.; NARIMATSU, S. KATAOKA, H.. Determination of polycyclic aromatic hydrocarbons in food samples by automated on-line in tube solid-phase microextraction coupled with high-performance liquid chromatography-fluorescence detection. Journal of Chromatography A, v.1217, n.35, p.5555-5563, 2010. DOI: https://doi.org/10.1016/j.chroma.2010.06.068

LIN, D.; ZHU, L.. Polycyclic aromatic hydrocarbons: pollution and source analysis of a black tea. Journal of Agricultural and Food Chemistry, v.52, p.8268-8271, 2004. DOI: https://doi.org/10.1021/if048636n

LIN, D.; TU, Y.; ZHU, L.. Concentrations and health risk of polycyclic aromatic hydrocarbons in tea. Journal of Agricultural and Food Chemistry, v.43, p.41-48, 2005. DOI: https://doi.org/10.1016/j.fct.2004.08.010

LONDOÑO, V. A. G.; REYNOSO, C. M.; RESNIK, S.. Polycyclic aromatic hydrocarbons (PAHs) in yerba mate (Ilex paraguariensis) from the Argentinean market. Food Addit Contam B., v.7, n.4, p.247-253, 2014. DOI: https://doi.org/10.1080/19393210.2014.919963

LONDOÑO, V. A. G.; REYNOSO, C. M.; RESNIK, S. L.. Polycyclic aromatic hydrocarbons (PAHs) survey on tea (Camellia sinensis) commercialized in Argentina. Food Control, v.50, p.31-37, 2015. DOI:

https://doi.org/10.1016/j.foodcont.2014.07.036

MAIRESSE, L. A. S.. Avaliação da bioatividade de extratos de espécies vegetais, enquanto excipientes de eloloquímicos. Tese (Doutorado em Agronomia) - Universidade Federal de Santa Maria, Santa Maria, 2005.

MEDEIROS, P. M.; SIMONEIT, B. R. T.. Analysis of sugars in environmental samples by gas chromatography-mass spectrometry. Journal of Chromatography A, v.1141, n.2, p.271-278, 2007. DOI: https://doi.org/10.1016/i.chroma.2006.12.017

PARIS, A.; LEDAUPHIN, J.; POINOT, P.; GAILLARD, J. L.. Polycyclic aromatic hydrocarbons in fruits and vegetables: Origin, analysis, and occurrence. Environmental Pollution, v.234, p.96-106, 2018. DOI: https://doi.org/10.1016/i.envpol.2017.11.028

PEREIRA, L. P.; LUZ, L. P.; TEDESCO, S. B.; SILVA, A. C. F.. Número de cromossomos em populações de Achyrocline satureioides Lam. (marcela) do Estado do Rio Grande do Sul, Brasil. Ciência Rural, Santa Maria, v.36, n.2, p.678-681, 2006. DOI: http://dx.doi.org/10.1590/S0103-84782006000200052

PINCEMAILLE, J.; SCHUMMER, C.; HEINEN, E.; MORIS, G. Determination of polycyclic aromatic hydrocarbons in smoked and non-smoked black teas and tea infusions. Food Chemistry, v.145, p.807-813, 2014. DOI: https://doi.org/10.1016/i.foodchem.2013.08.121

RENGARAJAN, T.; RAJENDRAN, P.; NANDAKUMAR, N.; LOKESHKUMAR, B.; RAJENDRAN, P.; NISHIGAKI, I.. Exposure 
to polycyclic aromatic hydrocarbons with special focus on cancer. Asian Pacific Journal of Tropical Biomedicine, v.5, n.3, p.182-189, 2015. DOI: https://doi.org/10.1016/S22211691(15)30003-4

RITTER, M. R.; SOBIERAJSKI, G. R.; SCHENKEL, E. P.; MENTH, L. A.. Plantas usadas como medicinais no município de Ipê, RS, Brasil. Revista Brasileira Farmacognosia, Maringá, v.12, n.2, p.51-62, 2002. DOI: http://dx.doi.org/10.1590/S0102$\underline{695 \times 2002000200001}$

SERPE, F. P.; ESPOSITO, M.; GALLO, P.; SERPE, L.. Optimization and validation of an HPLC method for determination of polycyclic aromatic hydrocarbons in mussels. Food Chemistry, v.122, n.3, p.920-925, 2010. DOI: https://doi.org/10.1016/j.foodchem.2010.03.062

SINGH, S.; VASHISHTH, A.. PAHs in some brands of tea. Environmental Monitoring and Assessment, v.177, p.35-38,
2011. DOI: https://doi.org/10.1007/s10661-010-1615-0

TFOUNI, S. A. V.; PADOVANI, G. R.; REIS, R. M.; FURLANI, R. P. Z.; CAMARGO, M. C. R.. Incidence of polycyclic aromatic hydrocarbons in vegetable oil blends. Food Control, v.46, p.539-543, 2004. DOI:

https://doi.org/10.1016/j.foodcont.2014.06.028

TRAN-LAM, T.; DAO, Y. H.; NGUYEN, L. K. T.; MA, H. K.; TRAN, H. N.; LE, G. T.. Simultaneous Determination of 18 Polycyclic Aromatic Hydrocarbons in Daily Foods (Hanoi Metropolitan Area) by Gas Chromatography-Tandem Mass Spectrometry. Foods, v.201, n.7, p.1-16, 2018. DOI: https://doi.org/10.3390/foods7120201

ZIEGENHALS, K.; JIRA, W.; SPEER, K.. Polycyclic aromatic hydrocarbons (PAHs) in various types of tea. European Food Research and Technology, v.228, p.83-91, 2018. DOI: https://doi.org/10.1007/s00217-008-0909-8

A CBPC - Companhia Brasileira de Produção Científica (CNPJ: 11.221.422/0001-03) detém os direitos materiais desta publicação. Os direitos referem-se à publicação do trabalho em qualquer parte do mundo, incluindo os direitos às renovações, expansões e disseminações da contribuição, bem como outros direitos subsidiários. Todos os trabalhos publicados eletronicamente poderão posteriormente ser publicados em coletâneas impressas sob coordenação da Sustenere Publishing, da Companhia Brasileira de Produção Científica e seus parceiros autorizados. Os (as) autores (as) preservam os direitos autorais, mas não têm permissão para a publicação da contribuição em outro meio, impresso ou digital, em português ou em tradução. 